\title{
Teaching students about death and other losses
}

\begin{abstract}
The purpose of this research is to investigate the extent to which the preconditions for the introduction of topics on death and other losses are met in primary schools. The aim was to examine the beliefs of primary school staff about teaching students on these topics and to examine their knowledge of the grieving process in children and youth. The sample consisted of 213 school staff from 13 primary schools in Zagreb and the surrounding area who met the Belief Scale on Teaching Students About Death and Other Losses and the Knowledge Test on the Grieving Process in Children and Youth. In this paper, the results of this empirical research are presented, which showed that primary school teachers have beliefs about higher self-competence for teaching students on the mentioned topics in relation to subject teachers. The results also showed the existence of a low positive correlation between beliefs about the usefulness of teaching about death and other losses and knowledge about the process of grieving children and young people. A low negative correlation was also found between the age of the participants and the results of the Knowledge Test. The conducted research brings practical implications that are important for further consideration of this topic and for the design of education for teachers and professional associates on the topic of grieving processes in children and youth.
\end{abstract}

Keywords: beliefs, knowledge, grief, loss, primary school

Paper type: Scientific paper

Received: $7 / 9 / 2021$

Accepted: 29/9/2021

DOI: $10.2478 /$ crdj-2021-0011

\section{Introduction}

We live in a society that denies death (Kastenbaum, 1981; according to Testoni, 2020). Topics related to mortality and losses have been marginalized for a number of reasons and are considered inappropriate (Lundgren et al., 2010). Avoiding these topics is especially emphasized in communication with children. Adults try to protect them in this way (van der Geest, 2015; Hulbert, 1999). Contradictory, there is evidence that in situations of loss, children often know that something serious and dangerous is happening and want honest information (Dalton, 2019). Furthermore, avoiding these topics results in isolating the child, who is thus left to itself. Consequently, children may develop irrational and dangerous attitudes about death (Testoni et al, 2019; according to Testoni, 2020), and their psychological resilience to coping in situations of loss is weak (Kastenbaum, 2000; Testoni, 2018; according to Testoni, 2020). All this can contribute to the development of many difficulties: depression, feelings of isolation, developing difficulties in creating close relationships in adulthood, psychiatric disorders, and even suicide in children and youth, which in Croatia, along with traffic accidents, is the leading cause of death (Cerel et al., 2006; Parson, 2011; Worden, 2005; Worden, 2002; according to Arambašić, 2008; Testoni et al, 2020; Croatian Institute of Public Health, 2017, according to Lendić, 2017). This 
information, in addition to the fact that due to the aging population most children and young people experience the loss of a family member or close friend by the age of sixteen (Harrison et al., 2001; according to Paul, 2019), supports the potential benefits of open dialogue on death and other losses with children and youth.

School is an environment in which children can gain a realistic perspective on death and other losses and support in grief. Numerous authors emphasize the importance of including these topics in schools (Andriessen et al., 2001; Chagnon et al., 2007; according to Testona 2020). Nevertheless, there is an almost complete absence of them in schools around the world (Wass, 2004). Only a small number of schools in America have pre-defined programs in which school staff teach students about death and other losses (Wass, 2004).

Although some researchers warn that talking about these topics could result in an intensification of fear (Mueller, 1975, according to Bailis et al., 1977), there are many more who point out the positive effects. Thus, Wells states that every situation should be used to talk to children about losses in order to gain a deeper understanding (1995, according to Higgins, 1999). Hulbert (1999) states that teaching about death could make it easier for students to integrate their losses into their experiences. Lee et al. (2009) showed that teaching about death for preschool children results in a greater understanding of this complex concept. Furthermore, research has shown that teaching can help children reject false beliefs about death, reduce their fear, help them face violence and death in the media, but also facilitate adequate contact with peers who are going through the grieving process (Testoni, 2020; Worden, 1996, according to Tracey et al., 2008; Durant, 2018). The results of an action study conducted in Cyprus showed that a careful and thoughtful pedagogical approach related to this controversial topic can help children demystify death and other losses and begin to address these topics in a more constructive and empathetic way (Stylianou et al., 2016). Research conducted in Italy has shown a reduction in alexithymia and the preservation of psychological well-being and life satisfaction after teaching about death (Testoni, 2020).

On the other hand, in addition to the many benefits of teaching students about losses, the literature often mentions the perception of insufficient preparation of teachers to deal with these topics (Cunningham et al., 1989; Pratt et al., 1987, according to Reid et al., 1999; Reid et al., 1999; Hogan et al., 1994; Patterson et al., 2010; Broberg et al., 2005, according to Dyregrov et al., 2013; McGovern et al., 2000).

Teachers from Quebec and Ontario consider these to be important topics, but express a lack of confidence to participate in such conversations (Engarhos et al., 2013). A survey conducted in the Netherlands found that $59 \%$ of school staff somewhat or completely agree with the statement that they know too little about helping ways to support students who have experienced loss (Dyregrov et al., 2013).

In Croatia, research has not yet addressed this topic, and since teaching about death and other losses is not part of the curriculum, its inclusion in teaching depends solely on the will, competencies and beliefs of primary and secondary school teachers and professional associates. In order to gain a better understanding of their perspective, we wanted to check if there are differences in beliefs and knowledge related to this topic, depending on their occupation. Primary school teachers acquire more thorough pedagogical-didacticmethodological qualifications in relation to subject teachers who have a broader main profession. In addition, the time pressure that teachers are exposed to, which is an aggravating circumstance for teaching on any topics not covered by the curriculum, is more pronounced in the work of subject teachers (Lowton et al., 2003). Primary school teachers teach almost all school subjects to the same class for the first four years. This offers them more freedom in organizing time. Given all the above, it is logical to assume that primary school teachers are more likely to deal with personal issues of their students and that, 
accordingly, they are more accustomed to such situations and have beliefs about higher self-competence to teach students personal, life topics, including death and other losses.

In addition to differences depending on the occupation, we wanted to examine other factors that proved to be relevant in individual studies. Thus, the research of Jones et al. (1995) examining the attitudes and knowledge of parents regarding the introduction of teaching primary school students about death and grief showed that parents who had greater knowledge about death and grief also expressed the greatest support for the introduction of such teaching in schools. Therefore, we assumed that school staff with more knowledge will have more positive beliefs. Also, McGovern et al. (2000) showed that parents are more aware than teachers that children suffer from loss equally as adults. In line with the above, we assumed that school staff who have their own child or children have more knowledge about grief than those who do not have a parental role in private life.

These hypotheses were set with the ultimate purpose of considering the readiness of primary schools to introduce these sensitive topics into the curriculum. Accordingly, the aim of this research is to examine the beliefs of teachers and professional associates about teaching students about death and other losses and their knowledge of the grieving process in children and youth.

\section{Methodology}

\section{Respondents and procedure}

The sample was a convenience sample and included a total of 213 employees from 13 primary schools in the city of Zagreb and the surrounding area. The age range of participants was 25-69 $(\mathrm{M}=45.56$; $S D=11.59)$. The range of years of service ranged from half to 42 years $(M=20.05 ; S D=11.79)$.

For the purposes of the research, 46 principals were contacted with the aim of obtaining consent to participate, but only 13 of them agreed.

Table 1

Overview of participant structure $(N=213)$

\begin{tabular}{lccc}
\hline \multirow{2}{*}{ Gender } & & $\mathbf{N}$ & $\mathbf{\%}$ \\
\hline Profession & Male & 15 & 7.04 \\
\cline { 2 - 4 } & Female & 198 & 92.96 \\
\cline { 2 - 4 } & Primary school teacher & 83 & 38.97 \\
\cline { 2 - 4 } & Subject teacher & 113 & 53.05 \\
\cline { 2 - 4 } & Professional & 17 & 7.98
\end{tabular}

associates:

\begin{tabular}{lccc}
\cline { 2 - 4 } & Educationalists & 8 & 3.75 \\
\cline { 2 - 4 } & Psychologists & 5 & 2.35 \\
\cline { 2 - 4 } Parenthood & Rehabilitators & 4 & 1.88 \\
\cline { 2 - 4 } & Yes & 142 & 66.67 \\
\hline
\end{tabular}

Source: Authors 


\author{
Figure 1 \\ Presentation of the structure of participants by profession \\ [strukturasudionika.jpg] \\ Source: Authors
}

A total of 442 sets of questionnaires were distributed, and $213(48.19 \%)$ were returned to the authors. The task of all participants was to complete three anonymous questionnaires lasting a total of approximately 40 minutes. This paper will present and analyze the results of the Belief Scale for Teaching Students about Death and Other Losses and the Knowledge Test on the Grieving Process in Children and Youth, which took a total of approximately 30 minutes to complete.

\title{
Measuring instruments
}

For the purposes of this research, a Belief Scale on Teaching Students About Death and Other Losses and a Knowledge Test on the Grieving Process in Children and Youth were constructed.

The Belief Scale consists of 24 particles constructed with the aim of examining two dimensions: the belief in the usefulness of such teaching and the belief in one's own competence for the same. Kaiser-Meyer-Olkin $(\mathrm{KMO}=0.888)$ and Bartlett test $(\mathrm{X} 2=$ 2399.988; $\mathrm{df}=276 ; \mathrm{p}<0.01$ ) determined that the correlation matrix of particles is suitable for factor analysis. An exploratory factor analysis was performed using the common factor method in which the number of factors was limited to 2 . The existence of two interpretable factors was shown: the factor of belief in the usefulness of teaching students about death and other losses and the factor of self-competence for such teaching. The 14-particle certificate of usefulness factor explains $32 \%$ of the total variance, while the 10-particle selfcompetence certificate factor explains $13 \%$ of the total variance. In this study, the reliability of the internal consistency type for the dimension of the certificate of utility is $\alpha=0.917$, while for the dimension of the certificate of self-competence is $\alpha=0.788$. Participants were offered a response scale of 1 to 4 in response to the statements, with 1 meaning "strongly disagree" and 4 meaning "strongly agree". The total score for each of the two dimensions is calculated as the arithmetic mean of the responses to the claims associated with each of the two dimensions. In this way, two overall results are formed. The theoretical range of overall scores for both dimensions is 1 to 4 . A higher overall score indicates beliefs about greater usefulness and higher self-competence for teaching students about death and other losses.

The first version of the Knowledge Test about the grieving process in children and young people consisted of 54 particles. Kaiser-Meyer-Olkin $(\mathrm{KMO}=0.615)$ and Bartlett test $(\mathrm{X} 2=$ 2666,$134 ; \mathrm{df}=1431 ; \mathrm{p}<0.01$ ) determined the suitability of conducting a factor analysis which showed, after limiting the number of factors to 1 , that 24 questionnaire particles refer to the factor of knowledge about the grieving process in children and young people. This factor described $12 \%$ of the total variance. Due to the negative association of the two particles with the factor, only 22 particles were retained in the further analysis. As many as 32 particles were thrown out of further processing because factor analysis indicates the great heterogeneity of their object of measurement.

Each correct answer on the particles is scored with one point and ultimately all the points are added up to form the overall score. The theoretical range of total scores is from 0 to 22 . 
A higher overall score represents greater knowledge. The reliability of the internal consistency type for the final test form in this study is $\alpha=0.843$.

\section{Results}

The Kolmogorov-Smirnov test showed that none of the three distributions of the results of the Belief Scale and the test of knowledge differed significantly from the normal one (see Table 2). In order to gain insight into the results, we will first present descriptive statistics of the results of the certificate scale and Knowledge Test, and then in Tables 3 and 4 of the particles of applied measuring instruments together with the answers of the participants.

\section{Table 2}

Review of Kolmogorov-Smirnov test results and descriptive statistics for the Belief Scale about teaching students about death and other losses and the test of knowledge about the grieving process in children and youth $(N=213)$

\begin{tabular}{lccccc}
\hline & $\boldsymbol{Z}$ & $\boldsymbol{M}$ & $\boldsymbol{S D}$ & Min & Max \\
\hline Beliefs on usefulness & 1.062 & 3.07 & 0.59 & 1 & 4 \\
\hline Beliefs on one's competence & 0.966 & 2.61 & 0.55 & 1 & 4 \\
\hline $\begin{array}{l}\text { Knowledge of the grieving } \\
\text { process of children and youth }\end{array}$ & 0.976 & 11.57 & 4.73 & 0 & 22 \\
\hline
\end{tabular}

Legend: $\mathrm{Z}$ - value of the Kolmogorov-Smirnov test.

Source: Authors

\section{Table 3}

Claims of the Belief Scale, arithmetic means, and standard deviations of responses $(N=205)$

\begin{tabular}{|c|c|c|}
\hline $\begin{array}{l}\text { The dimension of belief in the usefulness of teaching } \\
\text { students about death and other losses } \\
\text { *Offered answers: } \\
\begin{array}{ll}1=\text { strongly disagree } & 3=\text { somewhat agree } \\
2=\text { somewhat disagree } & 4=\text { strongly agree }\end{array}\end{array}$ & $\mathbf{M}$ & SD \\
\hline $\begin{array}{l}\text { 1. The introduction of teaching on death and other losses in primary } \\
\text { school would contribute to better preparation of students for life. }\end{array}$ & 2,9122 & 83554 \\
\hline $\begin{array}{l}\text { 2. Nothing can prepare children/young people to face death, so they } \\
\text { do not need to be bothered with such difficult topics. }\end{array}$ & 2,7659 & 96701 \\
\hline $\begin{array}{l}\text { 3. Teaching about death and other losses would help primary school } \\
\text { students provide support when one of their loved ones experiences } \\
\text { a loss. }\end{array}$ & 2,9951 & ,78277 \\
\hline $\begin{array}{l}\text { 4. I worry that teaching about death and other losses would } \\
\text { unnecessarily scare primary school students. }\end{array}$ & 2,7220 & 1,05522 \\
\hline $\begin{array}{l}\text { 5. By teaching about death and other losses, primary school } \\
\text { students would learn words to describe various aspects of death } \\
\text { and loss in general. }\end{array}$ & 2,8634 & 82894 \\
\hline $\begin{array}{l}\text { 6. Teaching about death and other losses in primary schools would } \\
\text { help students in the grieving process after experiencing loss. }\end{array}$ & 2,9659 & 85967 \\
\hline $\begin{array}{l}\text { 7. I am concerned about encouraging the development of mental } \\
\text { health problems by introducing primary school students to death } \\
\text { and other losses. }\end{array}$ & 2,8585 & ,99237 \\
\hline
\end{tabular}




\begin{tabular}{|c|c|c|}
\hline $\begin{array}{l}\text { 8. Teaching primary school students about death and other losses } \\
\text { would help students remove the fear of the unknown. }\end{array}$ & 2,9512 & 84457 \\
\hline $\begin{array}{l}\text { 9. I shudder at the thought of the damage that teaching about death } \\
\text { and other losses would do to primary school students. }\end{array}$ & 3,3366 & 90688 \\
\hline $\begin{array}{l}\text { 10. For many primary school children/young people, teaching about } \\
\text { death and other losses would encourage the development of } \\
\text { depression. }\end{array}$ & 3,1073 & ,93316 \\
\hline $\begin{array}{l}\text { 11. Teaching primary school students about death and other losses } \\
\text { would help students understand and accept their own feelings when } \\
\text { experiencing losses. }\end{array}$ & 3,0927 & ,78976 \\
\hline $\begin{array}{l}\text { 12. Teaching primary school students about death and other losses } \\
\text { would encourage aggressive student behavior. }\end{array}$ & 3,6780 & ,61338 \\
\hline $\begin{array}{l}\text { 13. Teaching primary school students about death and other losses } \\
\text { would encourage self-aggressive behavior in students (behavior } \\
\text { that manifests aggression directed towards oneself). }\end{array}$ & 3,5073 & ,71139 \\
\hline $\begin{array}{l}\text { 14. Teaching primary school students about death and other losses } \\
\text { would contribute to developing students' empathy toward grieving } \\
\text { people. }\end{array}$ & 3,2244 & 81553 \\
\hline $\begin{array}{l}\text { The dimension of belief on self-reliance for teaching } \\
\text { students about death and other losses }\end{array}$ & M & SD \\
\hline $\begin{array}{l}\text { *Offered answers: } \\
1=\text { strongly disagree }\end{array}$ & & \\
\hline $2=$ somewhat disagree $\quad 4=$ strongly agree & & \\
\hline $\begin{array}{l}\text { 15. Teaching students about death and other losses is an extremely } \\
\text { challenging task for me. }\end{array}$ & 1,5756 & ,79852 \\
\hline $\begin{array}{l}\text { 16. I do not think I need additional knowledge to teach students } \\
\text { about death and other losses. }\end{array}$ & 2,2293 & 1,26457 \\
\hline $\begin{array}{l}\text { 17. By no means would I be successful in teaching students about } \\
\text { death and other losses. }\end{array}$ & 2,8829 & 96302 \\
\hline $\begin{array}{l}\text { 18. If I do my best, I am sure I can successfully teach students about } \\
\text { death and other losses. }\end{array}$ & 3,1366 & 81702 \\
\hline $\begin{array}{l}\text { 19. During conversations with students about death and other } \\
\text { losses, I would not be able to control my strong feelings. }\end{array}$ & 2,8098 & 97413 \\
\hline $\begin{array}{l}\text { 20. I would be able to respond appropriately to students' emotional } \\
\text { reactions while teaching about death and other losses. }\end{array}$ & 3,0537 & ,79954 \\
\hline $\begin{array}{l}\text { 21. I am convinced that I can successfully deal with unexpected } \\
\text { situations while teaching students about death and other losses. }\end{array}$ & 2,9073 & 77725, \\
\hline $\begin{array}{l}\text { 22. I do not think I would be able to respond properly to possible } \\
\text { questions and comments from students while teaching about death } \\
\text { and other losses. }\end{array}$ & 2,5366 & ,93141 \\
\hline $\begin{array}{l}\text { 23. I would teach students about death and other losses with the } \\
\text { same ease with which I teach students about anything. }\end{array}$ & 2,3854 & 98159 \\
\hline $\begin{array}{l}\text { 24. I am worried that it would be very difficult for me to talk to } \\
\text { students about death and other losses. }\end{array}$ & 2,6634 & 96451 \\
\hline
\end{tabular}

Source: Authors

\section{Table 4}

Display of particles of the Knowledge Test, correct answers and percentage of participants who answered by agreeing ( $T$ ) and disagreeing ( $F$ ) ( $N=200$ to 213; depending on particles) 


\begin{tabular}{|c|c|c|c|}
\hline Particles & $\begin{array}{l}\text { Correct } \\
\text { answer }\end{array}$ & $\% \mathrm{~T}$ & $\% \mathrm{~F}$ \\
\hline 1. Grieving in children is generally easier than grieving in adults. & $\mathrm{F}$ & 41.6 & 58.4 \\
\hline 2. Grieving in children lasts shorter than grieving in adults. & $\mathrm{F}$ & 50.2 & 49.8 \\
\hline $\begin{array}{l}\text { 3. In contact with grieving children, it is desirable that adults do } \\
\text { not show that it is difficult for them as well. }\end{array}$ & $\mathrm{F}$ & 29.8 & 70.2 \\
\hline $\begin{array}{l}\text { 4. If the adults around the child react properly in a situation of } \\
\text { loss, the child can completely avoid feelings of suffering, } \\
\text { sadness, and pain. }\end{array}$ & $\mathrm{F}$ & 36.4 & 63.6 \\
\hline $\begin{array}{l}\text { 5. If the loss is a result of suicide, it would be advisable to tell the } \\
\text { child that it was an accident or illness so the child does not } \\
\text { become too anxious and worried that other loved ones would } \\
\text { commit suicide. }\end{array}$ & $\mathrm{F}$ & 79.7 & 20.3 \\
\hline $\begin{array}{l}\text { 6. When a child starts laughing or starts playing at the news of a } \\
\text { death of a loved one, it is a clear indication of the child's } \\
\text { insensitivity. }\end{array}$ & $\mathrm{F}$ & 5.2 . & 94.8 \\
\hline $\begin{array}{l}\text { 7. Grieving of a child after the death of an abusive parent will } \\
\text { generally be much easier than after the death of a parent with } \\
\text { whom the child had a good relationship. }\end{array}$ & $\mathrm{F}$ & 46.6 & 53.4 \\
\hline $\begin{array}{l}\text { 8. If the child is crying a lot, it is important to direct him/her to } \\
\text { something else to comfort him/her. }\end{array}$ & $\mathrm{F}$ & 58.7 & 41.3 \\
\hline $\begin{array}{l}\text { 9. Children and young people under the age of } 15 \text { should never } \\
\text { be taken to the last viewing of the deceased. }\end{array}$ & $\mathrm{F}$ & 41.5 & 58.5 \\
\hline $\begin{array}{l}\text { 10. If a child from the class dies, it is advisable to remove all } \\
\text { objects that may remind other students of the deceased child } \\
\text { soon as possible (e.g. artwork of the deceased on the wall, etc.). }\end{array}$ & $F$ & 12.0 & 88.0 \\
\hline $\begin{array}{l}\text { 11. After a loss, it is best to keep the child busy with other things } \\
\text { so he/she can forget about the loss. }\end{array}$ & $F$ & 69.8 & 30.2 \\
\hline $\begin{array}{l}\text { 12. Children and young people talking with a deceased parent is } \\
\text { one of the pathological reactions to loss. }\end{array}$ & $F$ & 28.3 & 71.7 \\
\hline $\begin{array}{l}\text { 13. Children of primary school age are less affected by loss than } \\
\text { adolescents. }\end{array}$ & $F$ & 36.8 & 63.2 \\
\hline $\begin{array}{l}\text { 14. After the loss, children and young people function well and } \\
\text { fulfill their own obligations only if they have not suffered from the } \\
\text { loss. }\end{array}$ & $F$ & 29.8 & 70.2 \\
\hline $\begin{array}{l}\text { 15. Breaking things (aggression) is not a natural and common } \\
\text { reaction to experiencing loss in children and young people. }\end{array}$ & $F$ & 50.5 & 49.5 \\
\hline $\begin{array}{l}\text { 16. Unlike adults, children generally do not blame themselves for } \\
\text { the death of a loved one. }\end{array}$ & $F$ & 45.0 & 55.0 \\
\hline $\begin{array}{l}\text { 17. When a child/young person shows learning difficulties even } \\
\text { a year after the loss, it is a matter of lack of interest or lack of } \\
\text { motivation, and not a reaction to the experienced loss. }\end{array}$ & $F$ & 22.9 & 77.1 \\
\hline $\begin{array}{l}\text { 18. Children and young people who seem to cope well } \\
\text { immediately after the loss are unlikely to have difficulties at } \\
\text { school later on. }\end{array}$ & $F$ & 23.6 & 76.4 \\
\hline $\begin{array}{l}\text { *Note for questions 19, 20, } 21 \text { and 22: read } \\
\text { ALL the options offered before completing } \\
\text { the answer. }\end{array}$ & $\begin{array}{l}\text { all of the } \\
\text { above }\end{array}$ & \multicolumn{2}{|c|}{$\begin{array}{c}\text { Other } \\
\text { answers }\end{array}$} \\
\hline
\end{tabular}


19. In my opinion, the natural, normal emotional reactions of children / young people to loss are (circle the letter in front of one or more such reactions):
a) sadness
h) longing for the deceased
b) anger
c) guilt and self-blame
i) a sense of "freedom"
d) anxiety and fear
j) relief
e) loneliness
k) jealousy
f) emptiness
l) all of the above
g) helplessness
$\mathrm{m})$ none of the above

20. In my opinion, the natural, normal mental reactions of children/young people to loss are (circle the letter in front of one or more such reactions):
a) shock and disbelief
d) thinking about revenge
b) loss of control
h) apparition of the decease
c) thinking about the deceased
i) searching for meaning
d) experience that the deceased
j) concern
is near us
k) all of the above
e) memory and concentration
l) none of the above
problems
f) pictures and thoughts about
the deceased

21. In my opinion, the natural, normal bodily reactions of children/young people to loss are (circle the letter in front of one or more such reactions):
a) "stomach emptiness"
b) "tightening" in the chest,
h) headache
throat
c) pain, pressure in the chest
i) dizziness
j) drowsiness
d) sensitivity to sounds
j) fatigue
I) all of the above
e) difficulty breathing (shallow, rapid, shortness of breath)
f) muscle weakness
d) dry mouth

22. In my opinion, the natural, normal behavioral reactions of children/young people to loss are (circle the letter in front of one or more such reactions):
a) difficulty sleeping
b) changes in apetite
c) avoiding social contact
d) dreams oft he deceased person
e)"excessive" activity
f) crying

h) emphasized care for

things that belonged to the

deceased

i) quarrelsomeness

j) aggresiveness

k) seeking justice,

guilt

I) all of the above 

g) going to places that
m) none of the above
remind of the deceased

Legend: $\mathrm{T}$ - true; F- false

Source: Authors

Table 5 shows the arithmetic means and standard deviations of the variables of age and years of service for primary and secondary school teachers, the values of t-tests that tested the difference between these groups and the corresponding degrees of freedom. It was found that there is no significant difference in the variables.

Table 5

Arithmetic means and standard deviations of age and years of work experience of primary and secondary school teachers, t-tests, corresponding degrees of freedom and size of performance (Cohen's d)

\begin{tabular}{|c|c|c|c|c|c|c|}
\hline 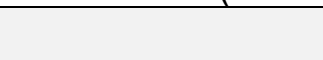 & Profession & $M$ & $S D$ & $t$ & $d f$ & $d$ \\
\hline \multirow[t]{3}{*}{ Age } & primary school teacher & 44.57 & 10.88 & - & 194 & - \\
\hline & $(N=83)$ & & & 1.69 & & 0.24 \\
\hline & $\begin{array}{l}\text { subject teacher } \\
(N=112)\end{array}$ & 47.33 & 11.65 & & & \\
\hline \multirow[t]{3}{*}{ Years of service } & primary school teacher & 20.46 & 11.35 & - & 194 & - \\
\hline & $(N=83)$ & & & 1.24 & & 0.03 \\
\hline & $\begin{array}{l}\text { subject teacher } \\
(N=113)\end{array}$ & 20.86 & 11.79 & & & \\
\hline
\end{tabular}

Source: Authors

Further analysis of the data showed that there was no significant correlation between the age of the participants and their beliefs, but a slight negative correlation was found between age and results on the Knowledge Test (Table 7). Thus, the older the participants, the lower their scores on the Knowledge Test. Given the low representation of men in the sample, it is not possible to determine the existence of differences in beliefs and knowledge depending on gender.

\section{Table 7}

Pearson's correlation coefficients between the results of the Knowledge Test and age of participants $(N=212)$, the Belief Scale about the usefulness of teaching students about death and other losses and their own competence for such teaching and the Knowledge Test about the grieving process in children and youth
Knowledge
Belief on
Belief on
usefulness
competence 


\begin{tabular}{cccc}
\hline Age & $-.274^{* *}$ & .086 & .092 \\
& $(N=212)$ & $(N=212)$ & $(N=212)$ \\
\hline
\end{tabular}

Legend: Knowledge - klowledge about the grieving process of children and youth; ${ }^{* *}-p<.01$.

Source: Authors

T-tests for large independent samples showed that classroom and subject teachers differ significantly in the results of the belief in their own competence (Figure 2), but not in the results of the belief in usefulness and knowledge. On average, primary school teachers achieve a significantly higher result on the Belief Scale about their own competence compared to subject teachers (Table 6).

Table 6

Arithmetic means and standard deviations of results on the Belief Scale about the usefulness of teaching students about death and other losses and their own competence for such teaching, test of knowledge about the grieving process in children and youth for primary and secondary school teachers, t-tests, corresponding degrees of freedom and size effect (Cohen's d)

\begin{tabular}{lccccccc}
\hline & $\begin{array}{c}\text { Primary } \\
\text { school } \\
\text { teachers }\end{array}$ & Subject teachers & & & \\
\hline & $\boldsymbol{M}$ & $\boldsymbol{S D}$ & $\boldsymbol{M}$ & $\boldsymbol{S D}$ & $\boldsymbol{t}$ & $\boldsymbol{d f}$ & $\boldsymbol{d}$ \\
\hline Usefulness & 2.97 & 0.64 & 3.12 & 0.58 & -1.74 & 194 & -0.25 \\
\hline Competence & 2.72 & 0.57 & 2.52 & 0.53 & $2.56^{*}$ & 194 & 0.37 \\
\hline Knowledge & 11.16 & 4.71 & 11.17 & 4.53 & -0.02 & 194 & -0.002 \\
\hline
\end{tabular}

Legend: Usefulness - beliefs about the usefulness of teaching students about death and other losses; Competence - beliefs about one's own competence for teaching students about death and other losses; Knowledge - knowledge of the grieving process in children and youth; $d$ - value of effect size (Cohen's d); ${ }^{*}-p<.05$.

Source: Authors

Figure 2

Presentation of results on a scale of self-competence to teach students about death and other losses

[uvjerenjaokompetentnosti.jpg]

Source: Authors

Pearson's correlation coefficients (Table 8) showed that there is a low positive correlation between the belief in usefulness and knowledge of the grieving process, while there is no significant correlation between the belief in self-competence and knowledge. Thus, participants who achieved higher results on the Knowledge Test also expressed their belief in the greater usefulness of teaching students about death and other losses.

\section{Table 8}


Pearson's correlation coefficients between the results on the Belief Scale about the usefulness of teaching students about death and other losses and their own competence for such teaching and the test of knowledge about the grieving process in children and young people

\section{Competence Knowledge}

\begin{tabular}{lcc}
\hline Usefulness & $.292^{* *}$ & $.229^{* *}$ \\
& $(N=213)$ & $(N=212)$ \\
\hline Competence & & -.047 \\
& & $(N=212)$
\end{tabular}

Legend: Usefulness - beliefs about the usefulness of teaching students about death and other losses; Competence - beliefs about one's own competence for teaching students about death and other losses; Knowledge - knowledge about the grieving process in children and young people; ${ }^{* *}-p<$ 01 .

Source: Authors

Figure 3

Presentation of the correlation between the results on the test of knowledge about the grieving process in children and young people and the belief in the usefulness of teaching students about death and other losses.

[korelacija.jpg]

Source: Authors

T-tests for large independent samples found that participants who have their own child or children do not differ significantly in the tested variables from those who do not (table 9).

\section{Table 9}

Arithmetic means and standard deviations of results on the Belief Scale about the usefulness of teaching students about death and other losses and their own competence for such teaching, Knowledge Test about the grieving process in children and youth for participants who have and do not have their own child/children, t-tests degrees of freedom and magnitude of effect (Cohen's $d$ )

\section{Parents Not parents}

\begin{tabular}{lccccccc}
\hline & $\boldsymbol{M}$ & $\boldsymbol{S D}$ & $\boldsymbol{M}$ & $\boldsymbol{S D}$ & $\boldsymbol{t}$ & $\boldsymbol{d} \boldsymbol{f}$ & $\boldsymbol{d}$ \\
\hline Usefulness & 3.09 & 0.58 & 3.02 & 0.64 & -0.25 & 0.868 & 0.11 \\
\hline Competence & 2.58 & 0.53 & 2.69 & 0.58 & 0.37 & -1.39 & -0.19 \\
\hline Knowledge & 11.28 & 4.72 & 12.14 & 4.76 & -0.002 & -1.254 & -0.18
\end{tabular}

Legend: Usefulness - beliefs about the usefulness of teaching students about death and other losses; Competence - beliefs about one's own competence for teaching students about death and other losses; Knowledge - knowledge of the grieving process in children and youth; $d$ is the value of the effect size (Cohen's d).

Source: Authors 


\section{Discussion}

Primary school teachers achieved higher results on the Belief Scale about their own competence compared to subject teachers, which is expected due to certain specifics that characterize these two professions. However, it should be emphasized that the difference in beliefs is relatively small, as evidenced by the size of the effect $(d=0.37)$. On the other hand, the hypothesis of higher beliefs about usefulness in subject teachers has not been confirmed. It is possible that, due to the more pronounced avoidance of these topics in contact with younger children, differences in beliefs about usefulness would arise when it comes to a larger age difference between students. In other words, the beliefs of high school teachers were also examined.

We also wanted to examine whether there is a link between beliefs about teaching students about death and other losses and knowledge about the grieving process in children and young people. The results showed that a significant, but weak, connection exists only between beliefs on usefulness and knowledge. In interpreting this finding, one should be careful because based on the results of the existence of a connection, we cannot conclude about a cause-and-effect relationship. It would be interesting to conduct research with an experimental design that would allow us to do so. When it comes to beliefs about competence and knowledge, it is possible that the results did not confirm the connection. This is so because most participants did not participate in education on the grieving process in children and youth, which means they gained information on this topic in various, more or less credible ways. Moreover, due to the lack of formal education, they did not have the opportunity to receive feedback, so they do not know how much they know. Contrary to the above, it is possible that participants who achieved higher results on the Knowledge Test, precisely because of greater knowledge are more aware of the complexity of this topic.

By considering the results on individual particles, it is possible to determine that the participants are afraid of the negative consequences of talking to students about loss, and that they have many inaccurate opinions about grieving children/youth.

When it comes to testing for differences depending on the parental role, the results did not confirm the hypotheses. It is possible that differences in usefulness have not been confirmed because parents are protective of their children. They often unrealistically try to protect them from all unpleasant experiences. Therefore, it is possible that, despite the parental role, teaching on these topics is not considered so useful. Furthermore, regardless of parenthood, all participants in our research are in daily contact with children and young people and had the opportunity to meet grieving students and thus gain information about the grieving process, which could affect their knowledge and beliefs about their competence.

Finally, the found weak negative correlation between the age of the participants and the results on the Knowledge Test suggests that the older respondents achieved poorer results. This connection could be a reflection of contemporary efforts to place greater importance on mental health. Accordingly, younger employees probably had the opportunity to attend a number of trainings on this topic, while gaining valuable information on grief.

Finally, the found weak negative correlation between the age of the participants and the results on the Knowledge Test suggests that the older respondents achieved poorer results. This connection could be a reflection of contemporary efforts to place greater importance on mental health. Accordingly, younger employees probably had the opportunity to attend a number of trainings on this topic, while gaining valuable information on grief.

It is important to be careful when interpreting the findings due to methodological shortcomings. The dropout rate was quite high, so it should be considered that there are relevant differences in the characteristics of participants who agreed to participate and 
those who refused, which were reflected in the results of this study. In addition, it would be useful to further develop measuring instruments in order to improve their metric characteristics. Here it is important to point out that special attention should be paid to the construction of the Knowledge Test because factor analysis showed that the particles are heterogeneous. As a result, an unusually large number of particles were ejected from further processing. It would be useful to determine a number of dimensions of knowledge and then design the particles that belong to each of these dimensions. An additional shortcoming of the Knowledge Test is the type of question. Namely, 4 particles questions where the respondents had to circle the correct answer, while the remaining particles are questions of the type true - false. Questions that require reproduction of the required content would better test knowledge. Finally, it is important to note that after the particles were removed from the Knowledge Test, all true answers became "false". Therefore, we can conclude that the constructed test primarily measures the recognition of false claims of grief.

\section{Conclusion}

The research conducted on a convenience sample of primary school staff from Zagreb and the surrounding area sought to consider the foundations related to the perspective of primary school staff, for the introduction of teaching about death and other losses in the school curriculum. The findings give us valuable information and insight into the knowledge of teachers and professional associates about the grieving process in children and youth and their beliefs related to the possible implementation of teaching on these topics in the school context.

A closer consideration of the participants' answers can help experts in designing education on the topic of grieving children and young people. Thus, based on the most commonly chosen wrong answers on the Knowledge Test, we can conclude that there is a tendency for school staff to interact with grieving students to send (direct or indirect) a message that they should not and/or not grieve. Also, given the frequent false to questions about natural reactions to grief, it is clear that school staff need to be educated that in a situation of loss, the reactions that would otherwise be judged to be deviant, are common. Finally, the answer to the Belief Scale shows the presence of fear of the negative consequences of teaching these topics to students. Therefore, a closer examination of the answers leads to the conclusion that the education of experts intended for school staff on this topic would be useful.

The results showed that primary school teachers have beliefs about a slightly higher selfcompetence to teach students about death and other losses compared to subject teachers. The differences in results between primary and secondary school teachers did not prove to be significant when it came to beliefs about usefulness and knowledge about the grieving process in children and young people. Furthermore, the results indicate a low positive correlation between knowledge of the grieving process and the belief in the usefulness of teaching students about death and other losses, but do not establish a correlation between knowledge and belief in self-competence. When comparing the above variables, no differences were found in participants who have and do not have their own child or children.

In order to further consider this poorly researched topic, it would be useful to further develop measurement instruments. It would also be desirable to examine other areas of Croatia and, by collecting a quota sample, enable testing of differences in variables between teachers and professional associates and men and women. In addition to the above, it is necessary to further investigate the reasons why primary school teachers have beliefs about higher self-competence to teach on these sensitive topics. What is more, further research on the nature of the established association between knowledge and belief in usefullness could bring valuable practical implications. Finally, considering the perspective and needs 
of parents and students would facilitate the final conclusion on the readiness of primary schools to implement topics related to death and kinds of loss, all with the aim of creating preconditions for quality and timely introduction of these topics in primary schools.

\section{References}

Arambašić, L. (2008). Gubitak, tugovanje, podrška. Naklada Slap. Jastrebarsko.

Bailis, L. A. and Kennedy, W. R. (1977). Effects of a death education program upon secondary school students. The Journal of Educational Research, 71(2), 63-66.

Cerel, J., Fristad, M.A., Verducci, J., Weller, R.A. and Weller, E. B. (2006). Childhood bereavement: Psychopathology in the 2 years postparental death. Journal of the American Academy for Child \& Adolescence Psychiatry, 45 (6), 681-690.

Cunningham, B. and Hare, J. (1989). Essential elements of a teacher in-service program on child bereavement. Primary School Guidance \& Counseling, 23(3), 175-182.

Dalton, L., Rapa, E., Ziebland, S., Rochat, T., Kelly, B., Hanington, L., ... \& Richter, L. (2019). Communication with children and adolescents about the diagnosis of a lifethreatening condition in their parent. The Lancet, 393(10176), 1164-1176.

Durant, K. L. (2018). How grief camp reinforces the need for death education in primary schools. Canadian Journal for New Scholars in Education/Revue canadienne des jeunes chercheures et chercheurs en éducation, 9(2).

Dyregrov, A., Dyregrov, K. and Idsoe, T. (2013). Teachers' perceptions of their role facing children in grief. Emotional and behavioural difficulties, 18(2), 125-134.

Engarhos, P., Talwar, V., Schleifer, M., \& Renaud, S. J. (2013). Teachers' attitudes and experiences regarding death education in the classroom. Alberta Journal of Educational Research, 59(1), 126-128.

Higgins, S. (1999). Death education in the primary school [1]. International Journal of Children's spirituality, 4(1), 77-90.

Hogan, N. S., De Santis, L., Demi, A. S., Cowles, K. V., \& Ross, H. M. (1994). Things that help and hinder adolescent sibling bereavement. Western Journal of Nursing Research, 16(2), 132-153.

Hulbert, F. (1999). Teaching about loss, change, death and bereavement in the Primary school. The Journal od Progressive Judaism, 13, 79. - 92.

Jones, C. H., Hodges, M. and Slate, J. R. (1995). Parental support for death education programs in the schools. The School Counselor, 42(5), 370-376.

Lee, J. O., Lee, J. and Moon, S. S. (2009). Exploring children's understanding of death concepts. Asia Pacific Journal of Education, 29(2), 251-264.

Lendić, M. (2017). Prevencija suicida kod mladih LGBT osoba (Doctoral dissertation, University of Zagreb. Faculty of Education and Rehabilitation Sciences).

Lowton, K. and Higginson, I.J. (2003). Managing bereavement in the classroom: A conspiracy of silence? Death studies, 27 (8), 717-741.

Lundgren, B. S., \& Houseman, C. A. (2010). Banishing death: The disappearance of the appreciation of mortality. OMEGA-Journal of Death and Dying, 61(3), 223-249.

McGovern M. and Barry, M. M. (2000). Death education: Knowledge, attitudes, and perspectives of Irish parents and teachers. Death studies, 24(4), 325-333. 
Patterson, P., \& Rangganadhan, A. (2010). Losing a parent to cancer: A preliminary investigation into the needs of adolescents and young adults. Palliative and Supportive Care, 8(03), 255-265.

Paul, S. (2019). Is death taboo for children? Developing death ambivalence as a theoretical framework to understand children's relationship with death, dying and bereavement. Children \& Society, 33(6), 556-571.

Reid, J. K. and Dixon, W. A. (1999). Teacher attitudes on coping with grief in the public school classroom. Psychology in the Schools, 36(3), 219-229.

Stylianou, P., \& Zembylas, M. (2018). Dealing with the concepts of "grief" and "grieving" in the classroom: children's perceptions, emotions, and behavior. OMEGA-Journal of Death and Dying, 77(3), 240-266.

Testoni, I., Tronca, E., Biancalani, G., Ronconi, L., \& Calapai, G. (2020). Beyond the wall: death education at middle school as suicide prevention. International journal of environmental research and public health, 17(7), 2398.

Tracey, A. and Holland, J. (2008). A comparative study of the child bereavement and loss responses and needs of schools in Hull, Yorkshire and Derry/Londonderry, Northern Ireland. Pastoral Care in Education, 26(4), 253-266.

van der Geest, I. M., van den Heuvel-Eibrink, M. M., van Vliet, L. M., Pluijm, S. M., Streng, I. C., Michiels, E. M., ... \& Darlington, A. S. E. (2015). Talking about death with children with incurable cancer: perspectives from parents. The journal of pediatrics, 167(6), 1320-1326.

Wass, H. (2013). Helping children cope with death. In Children and death (pp. 35-56). Taylor \& Francis.

Worden, (2005). Savjetovanje i terapija u tugovanju: priručnik za stručnjake iz područja zaštite mentalnog zdravlja. Naklada Slap. Jastrebarsko.

\section{About the authors}

Doris Veronika is a psychologist who graduated from the Faculty of Humanities and Social Sciences. She is the coordinator of the Center for Careers and Support for Students and Teachers of University College Aspira. She participates in teaching the course Business Communication for Students and as part of numerous lifelong learning programs at the University College Aspira and the Contemporary Training Centre in Split. She is an educator for expressive art therapy practitioners. The author can be contacted at doris.veronika@aspira.hr.

Lidija Arambašić is a psychologist who graduated and received her doctorate from the Faculty of Humanities and Social Sciences, where she teaches several courses at the Department of Psychology. She is a full professor. Her areas of interest are stress, trauma, loss, the grieving process, and psychological crisis interventions. She is the leader of many trainings for professionals in helping professions, and provides psychological support to people who are grieving and people in crisis. In addition to numerous scientific and professional papers, she also wrote the university textbook Gubitak, tugovanje, podrška (Loss, Grief, Support (2005)). 